\title{
Physical and Mechanical Properties of Wood-Cement Composite with Lignocellulosic Grading Waste Variation
}

\author{
Renato Marini Ronquim ${ }^{1}$, Fabiane Salles Ferro², Felipe Hideyoshi Icimoto², Cristiane Inácio Campos ${ }^{1}$, \\ Marília da Silva Bertolini ${ }^{2}$, André Luis Christoforo ${ }^{3, *}$, Francisco Antonio Rocco Lahr ${ }^{2}$ \\ ${ }^{1}$ Wood Industrial Engineering, State University of São Paulo "Júlio de Mesquita Filho”, Itapeva, 18409-010, Brazil \\ ${ }^{2}$ Department of Science and Material Engineering, Engineering School of São Carlos (EESC/USP), São Carlos, 13566-590, Brazil \\ ${ }^{3}$ Department of Civil Engineering (DECiv), Federal University of São Carlos, São Carlos, 13565-905, Brazil
}

\begin{abstract}
This research aimed verifies, with the aid of the analysis of variance (ANOVA), the influence of particles size of Eucalyptus grandis wastes in density and modulus of elasticity and strength modulus in compression of wood-cement composites. For this study was performed production and characterization of specimens, using portland cement, water and particle waste of Eucalyptus wood species, classified into sieves 10,20,32 and 60 mesh. The results of ANOVA showed significant differences in particle size, while samples with smaller particles had higher densities and lower mechanical performances. The composites studied have fully capable of being used as paving blocks, pavers or closure without the need for structural performance panels.
\end{abstract}

Keywords Waste, Composite, Cement, Wood, Analysis of variance, Compression tests

\section{Introduction}

The timber industry in Brazil is a poor segment in technology and engineering in the use of raw material, generating large amounts of waste from wood processing. Approximately $50 \%$ of the original volume of logs ends up as waste [1].

The waste generated from wood industries should receive disposal proper, because improper disposal can lead to environmental damage and economic problem for the companies themselves, due to the receipt of fines. Many studies use the waste from wood industries as raw material for manufacture of composites such as wood based panels, cement slabs, plastic-wood and also for the manufacture of fertilizers through composting, thus reducing the problems of waste generation..

The wood-cement panels are basically formed by wood particles, cement (Portland) and water. Other components are added to maximize the quality of the process and the properties of the product [2].

Cementitious composites have many applications such as thermal and acoustic insulation, fire resistant cladding, etc., and have advantages, such as low density when compared to the concrete, better performance to resist weathering, fire, fungi and insect attacks when compared to wood [3-4].

* Corresponding author:

alchristoforo@yahoo.com.br (André Luis Christoforo)

Published online at http://journal.sapub.org/cmaterials

Copyright (C) 2014 Scientific \& Academic Publishing. All Rights Reserved
In many parts of the world, fibrocement material already part of technology programs, especially as regards the coverage of low-cost systems, as reported by Delvasto [5].

The studies of the application of wood fibers in concrete has been driven by its low cost, availability, energy saving and also with regard to environmental issues $[3,6]$.

The species of wood used in the manufacture of cement-composites significantly influences its properties. In general, the coniferous woods have higher chemical compatibility with cement than hardwoods, which contain larger amounts of components that inhibit the reactions of Portland cement. The idea of mixing cement, sawdust and water are only possible in a direct way to a small number of wood species. Most have certain chemicals that are released during hydration of cement chemical reactions, inhibiting or even preventing the connection between the wood particles [7-8].

The particle size is another key factor in the properties of the wood-cement composites. In the industrial process, appropriate particle size should be between 2 to $20 \mathrm{~mm}$ long, 0.2 to $2.5 \mathrm{~mm}$ wide and 0.3 to $0.9 \mathrm{~mm}$ thick [9]. Besides the remarkable influence on the property of bending, cement consumption is also significantly influenced by particle size, because the larger specific surface of the particles will be greater the amount of cement paste to engage them, and consequently, the more of water required for the formation of this folder [4].

This research aimed verifies the influence of particle size in physical and mechanical properties of wood-cement composite manufactured with Eucalyptus grandis wood 
waste with different particle size.

\section{Material and Methods}

To develop this work, it was used Eucalyptus grandis wastes obtained in the Wood Processing Laboratory of the State University of São Paulo "Julio de Mesquita Filho", Itapeva Campus (SP-Brazil).

First the wastes were processed in a mincer knives and a hammer mill with the aim of reducing its dimensions. After completion of the milling, the particles were classified according to their granulometry, in sieves of 10, 20, 32 and 60 mesh [10-11]. The particles had a moisture content of approximately $12 \%$.

The cement used in the production of the samples was the Portland II and CP-32. The choice of concrete is related to its greater availability in the market, more affordable prices, wider application in construction and the absence of elements in its composition that does not become more expensive product.

It were evaluated four particle size, been produced six specimens with $1200 \mathrm{~g}$ of cement, $240 \mathrm{~g}$ of wood and $720 \mathrm{~g}$ of water for each experimental condition (Table 1). In total, twenty-four specimens were produced for this study.

Table 1. Experimental program

\begin{tabular}{cc}
\hline Experimental Condition (EC) & Mesh \\
\hline C1 & 10 \\
C2 & 20 \\
C3 & 32 \\
C4 & 60 \\
\hline
\end{tabular}

For the production of the composite the ratio of mixture components used was 1:0.2:0.6 corresponding quantities of concrete, wood and water, respectively. The mixture of these materials was carried out manually until a homogeneous mixture of the added constituents.

For the molding of the specimens, we used PVC molds with dimensions established according to standard ABNT NBR 7215 [12], with $50 \mathrm{~mm}$ diameter and $100 \mathrm{~mm}$ in height (Figure 1a). Oil release agent was applied in molds to facilitate the removal of the specimens after pre-cure these.

To occurs the complete hardening of the cement, as normative specification, the test samples were conditioned (Figure 1b) by twenty-eight days. After this period, tests for the determination of density, modulus of elasticity (E) and tensile strength (S) in axial compression have been performed, proceeded according to satnadrad ABNT NBR 7215 [12].

To investigate the influence of particle size of wood waste on the properties of interest, was used the analysis of variance (ANOVA), with the aid of Minitab ${ }^{\circledR}$ software, version 14 , evaluated at the $5 \%$ significance level $(\alpha)$, having the equivalence of means between treatments as null hypothesis $\left(H_{0}\right)$ and the non-equivalence as an alternative hypothesis $\left(H_{l}\right)$. P - value less than the significance level implies rejecting $H_{0}$, accepting it otherwise.

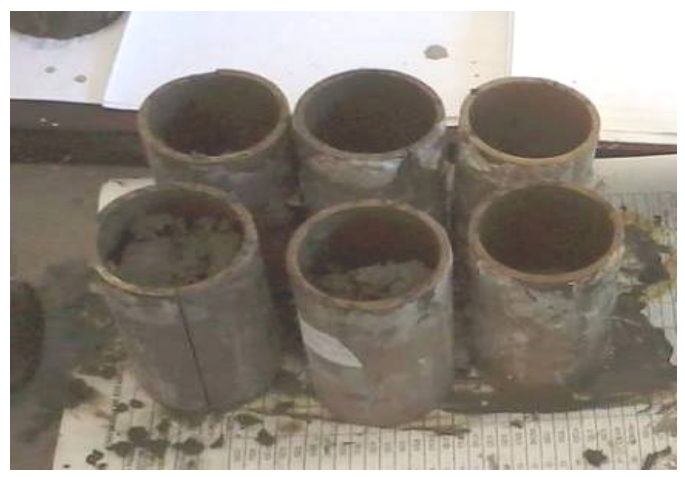

(a)

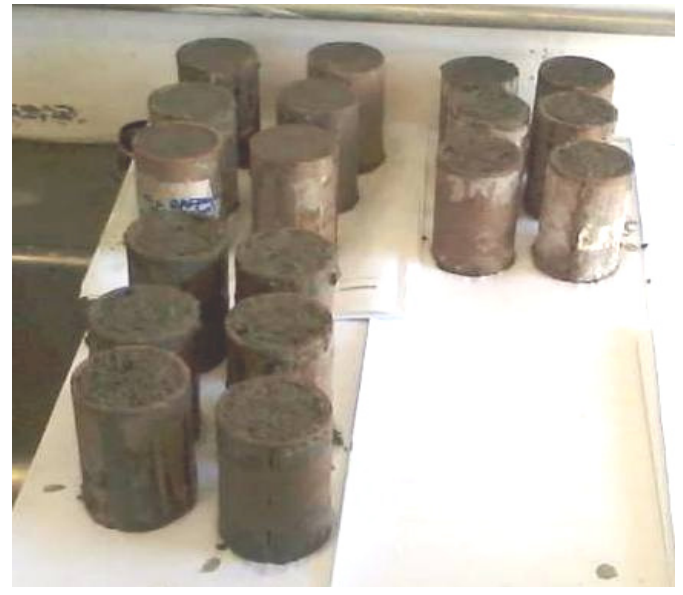

(b)

Figure 1. Specimens manufacture. a) PVC molds. b) Specimens conditioned

For validation of ANOVA were tested the normality of the response distributions (Anderson-Darling test) and homogeneity of variances among treatments ( $F$ test), both considered at the $5 \%$ significance level. The formulations of testing, $\mathrm{P}$-value greater than 0.05 implies that the response distribution is normal and the variances between treatments are homogeneous, which validates the ANOVA model. Accused significance of the factor by the ANOVA, was used the Tukey multiple comparisons test in order to elect the best treatment by propertie. The results were compared with related research and with the standard ABNT NBR 7215 [12].

\section{Results and Discussions}

Table 2 shows the mean results $(\bar{x})$ and the coefficients of variation $(C v)$ obtained for each experimental condition (EC) for the density, and the results of the Tukey test (grouping Gp.). The results of the normality $(0.326)$ and the homogeneity of variances $(0.581)$ tests present P-values superior to 0.05 , indicating that the distribution is normal and the variances are homogeneous, which validates the ANOVA model. Tukey's test, the same letters imply treatments with equivalent means. 
Table 2. Mean values, coefficients of variation and Tukey's test results for density

\begin{tabular}{cccc}
\hline $\boldsymbol{E C}$ & $\overline{\boldsymbol{x}}\left(\mathbf{g} / \mathbf{c m}^{3}\right)$ & $\boldsymbol{C} \boldsymbol{v}(\%)$ & $\boldsymbol{G} \boldsymbol{p}$. \\
\hline $\mathrm{C} 1$ & 1.16 & $1 \%$ & $\mathrm{~A}$ \\
$\mathrm{C} 2$ & 1.20 & $2 \%$ & $\mathrm{AB}$ \\
$\mathrm{C} 3$ & 1.25 & $3 \%$ & $\mathrm{~B}$ \\
$\mathrm{C} 4$ & 1.23 & $2 \%$ & $\mathrm{BC}$ \\
\hline
\end{tabular}

The values found for the density (Table 2) are compatible those found in the literature. Iwakiri et al. [13] determined to cement composites manufactured with Paricá (Schizolobium amazonicum) wood species and Embaúba (Cecropia hololeuca) density of $1.2 \mathrm{~g} / \mathrm{cm}^{3}$. Silva et al. [2] found density of $1.34 \mathrm{~g} / \mathrm{cm}^{3}$ for wood-cement composite manufactured with bark of Eucalyptus urophylla S.T. Blake. All experimental conditions had low coefficients of variation for the density property.

It is observed in Table 2 that the experimental conditions $\mathrm{C} 1$ and $\mathrm{C} 3$ had means that differed statistically among themselves, implying be influential at particle size on the density of wood-cement composites.

The particle size reduction gave a significant increase in density. This increased density is related to increased surface contact, in terms of volume, caused by the reduction of particulate matter. Due to increased contact between the particles decrease the voids of the composite, thereby increasing its density.

Table 3 shows the mean results $(\bar{x})$ and the coefficients of variation $(C v)$ obtained for each experimental condition (EC) for the modulus of elasticity (E) and strength (S) in compression, and the results of the Tukey test. The results of the normality $[0.127 ; 0.435]$ and the homogeneity of variances $[0.276 ; 0.681]$ tests present $\mathrm{P}$-values superior to 0.05 , evidencing that the distribution is normal and the variances are homogeneous, which validates the ANOVA model. Tukey's test, the same letters imply treatments with equivalent means.

Table 3. Mean values, coefficients of variation and Tukey's test for the mechanical properties

\begin{tabular}{cccc}
\hline $\boldsymbol{E} \boldsymbol{C}$ & $\overline{\boldsymbol{x}}$ & $\boldsymbol{C} \boldsymbol{v}(\boldsymbol{M} \boldsymbol{\%} \boldsymbol{a})$ & $\boldsymbol{G} \boldsymbol{p}$. \\
\hline 1 & 362,71 & $18 \%$ & $\mathrm{~A}$ \\
2 & 402,72 & $16 \%$ & $\mathrm{~A}$ \\
3 & 379,12 & $24 \%$ & $\mathrm{~A}$ \\
4 & 198,43 & $28 \%$ & $\mathrm{~B}$ \\
\hline $\boldsymbol{E} \boldsymbol{C}$ & $\overline{\boldsymbol{x}}$ & $\boldsymbol{C} \boldsymbol{( M P} \boldsymbol{( \% )}$ & $\boldsymbol{G} \boldsymbol{p}$. \\
\hline 1 & 4,00 & $5 \%$ & $\mathrm{~A}$ \\
2 & 4,26 & $5 \%$ & $\mathrm{~A}$ \\
3 & 3,04 & $5 \%$ & $\mathrm{~B}$ \\
4 & 2,70 & $11 \%$ & $\mathrm{~B}$ \\
\hline
\end{tabular}

Through the analysis of variance (Table 3), it was found that the $\mathrm{E}$ for the experimental condition $\mathrm{C} 4$ differed significantly from the other conditions, indicating significant influence of particle size on this property. The reduction of particle size caused significant reductions in the compression modulus of elasticity. The largest absolute value was observed in the experimental condition C2, with 402.72 MPa.

Compression modulus of elasticity values found in the literature range from 277 to $601 \mathrm{MPa}$ for cement composites manufactured with Eucalyptus grandis wood and manganese slag [14]. The values obtained in this research were lower than those found by Missagia et al. [15] (906 MPa), working with Ipe wood species and epoxy resin.

Regarding compression strength, the decrease in particulates size in the manufacture of wood-cement composites provided significant reductions in this property, and the experimental conditions $\mathrm{C} 1$ and $\mathrm{C} 2$ differed statistically from $\mathrm{C} 3$ and $\mathrm{C} 4$ conditions.

The smaller the wood particle size greater absorption of water, which reduces the mechanical performance of cement composites [4]. The experimental conditions $\mathrm{C} 1$ and $\mathrm{C} 2$ are the best solutions because they have higher values for the modulus of elasticity and compression strength properties.

Compression strength values found in literature range from $4 \mathrm{MPa}$ to cement composites manufactured with wood Southern Pine [16] and from 3.6 to $6.9 \mathrm{MPa}$ for different particles sizes and Eucalyptus species [17].

The results obtained for the compression strength property for all experimental conditions ranged 0.69 and $5.5 \mathrm{MPa}$, needed for applications such as acoustical and thermal insulators [18]. Wood-cement panels commercially present values of strength modulus in compression around 110 $\mathrm{kgf} / \mathrm{cm}^{2}[19]$.

The coefficients of variation obtained for the modulus of elasticity and compression strength did not exceed $30 \%$ and $10 \%$, respectively, and are consistent with those obtained by Matoski [20] and Missagia et al. [15].

\section{Conclusions}

The evaluated treatments with different wood particles sizes showed significant differences in their density and compressive strengths. Smaller particles had a higher density due to the presence of fewer voids in the structure of specimens, and to lower the mechanical compression strength due to a greater absorption of water by the particles of Eucalyptus.

It can be noticed that in this case, the density was inversely proportional to the strength in compression, which makes it even more viable and interesting composite, because with lower density material has better compressive strength, a very common aspect of composite materials.

The larger particles, as observed in treatments $\mathrm{C} 1$ and $\mathrm{C} 2$, with particles 10 and 20 mesh, respectively, are more appropriate for use in the production of wood-cement composite, indicating a viable for applications such as flat sheets for thermal and acoustic insulation. It also states the possibility of using the composite paving blocks, pavers or 
closure without the need for structural performance panels.

\section{REFERENCES}

[1] A. Sales, F. R. Souza, F. C. R. Almeida. Mechanical properties of concrete produced with a composite of water treatment sludge and sawdust, Construction and Building Materials. 25, 2793-2798, 2011.

[2] G. C. Silva, J. V. F. Latorraca, D. E. Teixeira, G. B. Júnior. Wood and bark composite production of Eucalyptus urophylla and cement Portland, Scientia forestalis. 68, 59-67, 2005.

[3] P. Coatanlem, R. Jauberthie, F. Rendell. Lightweight wood chipping durability, Constr Build Mater. 20, 776-781, 2006.

[4] A. Matoski, S. Iwakiri. Evaluation of physical and mechanical panels cement using wood flour wood with controlled particle size, Floresta. 37, 149-158, 2007.

[5] S. A. Delvasto, R. Gutierrez, M. M. Lopez. Como hacer tejas com fibra de fique. Departamento de materiales de ingeniería. Universidad del Valle, 1995.

[6] R. S. P. Coutts. A review of Australian research into natural fibre cement composites. Cement and Concrete Composites. Austrália, 2005.

[7] J. G. Keles. Investigação da resistência ao fogo de uma argamassa aditivada com fibras vegetais. 2011. $125 \mathrm{f}$. Dissertação (Mestrado) - Curso de Engenharia Dos Materiais, Universidade Federal de Ouro Preto, Ouro Preto, 2011.

[8] A. M. Batista. A influência do tratamento em compósitos de cimento-madeira, Projeções. 19/20, 1-3, 2002.

[9] S. Iwakiri, A. B. Cunha, C. E. C. Albuquerque, E. Gorniak, L. M. Mendes. Resíduos de serraria na produção de painéis de madeira aglomerada de Eucalipto, Scientia Agrária. 1, 23-28, 2001.

[10] M. S. Bertolini. Produção e avaliação das propriedades físico-mecânicas de compósitos lignocelulósicos produzidos a partir de madeira de Pinus sp., bambu da espécie Dendrocalamus giganteus e cimento portland. 2009. $104 \mathrm{f}$. Monografia - Curso de Engenharia Industrial Madeireira,
Universidade Estadual Paulista, Itapeva, 2009.

[11] R. M. Ronquim. Produção e caracterização físico-mecânica do compósito cimento-madeira com variação granulométrica dos resíduos lignocelulósicos. 2013. 2013. 53 f. Monografia Curso de Engenharia Industrial Madeireira, Universidade Estadual Paulista, Itapeva, 2013.

[12] Associação Brasileira de Normas Técnicas. NBR 7215: Cimento Portland - Determinação da resistência à compressão. Rio de Janeiro. 1996.

[13] S. Iwakiri, L. S. Silva, R. Trianoski, G. M. Bonduelle, V. Y. Rocha. Evaluation of potentical use of the wood of Schizolobium amazonicum "Paricá" and Cecropia hololeuca "Embaúba" for wood cement board manufacture, Revista Cerne. 18, 303-308, 2012.

[14] F. C. R. Dinhane,; C. I. Campos, B. S. Ferreira. Análise do compósito cimento-madeira-escória. In: Congresso Brasileiro de Engenharia e Ciência dos Materiais, 20. 2012, Joinville. Anais... Joinville: CBECIMAT, p. 1 - 8, 2012.

[15] Z. M. V. Missagia, J. C. Santos, T. H. Panzera, L.C. Brandão, D. A. L. Silva, A. L. Christoforo. Particulate composite material in epoxy matrix reinforced with sawdust, cement and magnesium silicate, Ambiente Construído. 13, 285-302, 2013.

[16] A.W.C. Lee. Physical and mechanical properties of cement bonded southern pine excelsior board. Forest Products Journal, 34, 30-34, 1984.

[17] J. V. F. Latorraca, S. Iwakiri. Effect of particle treatment of eucalyptus dunni (maid), wood:cement ratio and additives on the physical and mechanical properties of wood-cement boards, Revista Cerne. 6, 68-76, 2000.

[18] J. A. Youngquist. Wood Based composites and panel products-Wood Handbook -Wood as an engineering material - Madison, WI - pg. 10.1; 10-31 - USA, 1999.

[19] Viroc. Características viroc. Disponível em: $<$ http://www.vir oc.pt>. Acesso em: 12 dez. 2013.

[20] A. Matoski. Utilização de pó de madeira com granulometria controlada na produção de painéis de cimento-madeira. 2005. 202 f. Tese (Doutorado) - Curso de Engenharia Florestal, Departamento de Ciências Agrárias, Universidade Federal do Paraná, Curitiba, 2005. 